\title{
11. REE AND TRACE ELEMENT COMPOSITION OF CLINOPYROXENE MEGACRYSTS, XENOCRYSTS, AND PHENOCRYSTS IN TWO DIABASE DIKES FROM LEG 140, HOLE 504B ${ }^{1}$
}

\author{
Henry J.B. Dick ${ }^{2}$ and Kevin T.M. Johnson ${ }^{3}$
}

\begin{abstract}
We report the major, rare earth, and other trace element compositions of clinopyroxenes from two Leg 140, Hole 504B diabase dikes. These pyroxenes reflect a complex history of crystal growth and magma evolution. The large ranges of composition found reflect incorporation of exotic phenocrysts into the melt, the early formation of crystal clots before dike intrusion during an undercooling event, and in-situ fractionation of melt during and following dike emplacement. Some of the pyroxenes occur in coarse two- and three-phase glomerocrysts, which may be "protogabbros" representing early stages of melt crystallization in the lower crust. Large variations in trace element composition are found. These likely reflect heterogeneous nucleation and growth of plagioclase and pyroxene in the melt, as well as complex interface kinetics that may affect partition coefficients during rapid crystal growth expected during undercooling. This can explain the formation of irregular chemical sector zoning in some equant anhedral phenocrysts. Undercooling of magmas in the lower crust most likely reflects input of fresh hot melt into a stagnating melt-storage zone. Dikes intruded upward from an inflated melt-storage zone during such a cycle are likely to be larger than those intruded from the storage zone between such cycles, when it would be deflated, consistent with the greater overall thickness of the phyric dikes in the Leg 140 section of Hole 504B.
\end{abstract}

\section{INTRODUCTION}

This paper reports electron and ion microprobe analyses of major, rare earth, and trace elements in groundmass, phenocryst, glomerocryst, and megacryst clinopyroxenes in two plagioclaseclinopyroxene-olivine moderately phyric diabase dikes drilled during Leg 140 at Hole 504B. The Leg 140 scientific party chose to refer to the diverse assemblage of relatively coarse glomerocrysts as crystal clots to avoid any direct genetic connotations or the temptation of directly relating rather small, possibly non-representative crystal clots to often highly heterogeneous plutonic lithologies such as olivine gabbro, troctolite, or wehrlite.

The complex phenocryst assemblages are distinguished by the presence of both bright kelly green endiopside and black augite phenocrysts. The appearance of the former, relatively chrome-rich clinopyroxenes at first suggests an exotic mantle origin for some of the megacrysts and glomerocrysts. This study shows, however, that these crystals represent relatively rapid crystallization during an undercooling event. These aggregates, and the individual megacrysts and xenocrysts, are thought to have crystallized in the subaxial magma storage system, and reflect magma-mixing, undercooling, melt-rock interaction, and crystal fractionation occurring as the magmas were intruded into the crust and successively migrated upward toward the surface.

\section{ANALYTICAL TECHNIQUE}

Major elements were analyzed using the electron microprobe in the Department of Earth and Planetary Sciences at the Massachusetts Institute of Technology using natural mineral standards. Rare earth and other trace elements were analyzed using the Cameca IMS $3 \mathrm{f}$ ion microprobe in the Department of Geology and Geophysics at the Woods Hole Oceanographic Institution, with Dr. Nobu Shimizu assisting in the analyses using techniques described in Johnson et al. (1990). A detailed discussion of the accuracy and precision of the analyses can be found in that reference, but they are approximately

'Erzinger, J., Becker, K., Dick. H.J.B., and Stokking. L.B. (Eds.), 1995. Proc. ODP Sci. Results, 137/140: College Station, TX (Ocean Drilling Program).

${ }^{2}$ Department of Geology and Geophysics, Woods Hole Oceanographic Institution. Woods Hole, MA 02543, U.S.A.

${ }^{3}$ Department of Natural Sciences, Bishop Museum. Honolulu, HI 96817, U.S.A. $\pm 20 \%$ for the light rare earth elements (REE), and $\pm 10 \%-15 \%$ for the heavy $\mathrm{REE}, \mathrm{Sr}$, and $\mathrm{Zr}$, and $\pm 2 \%-5 \%$ for $\mathrm{Ti}, \mathrm{V}$, and $\mathrm{Cr}$. All analyses were done on polished thin sections, with the analytical locations recorded by photographing the burn spots from the ion beam on the gold-plated thin sections in polarized light. These photos were then used to relocate the same points after the samples had been cleaned and recoated with carbon for electron microprobe analysis. Point numbers are given for cross-reference in Tables 1 and 2, and are shown in Plate 1.

\section{STRATIGRAPHY AND PETROLOGY}

The samples selected for analysis are located in dike Units 211 (140-504B-186R-1, 4-6 cm, and 16-18 cm) and 227 (140-504B200R-2, 30-35 cm, and $-200 \mathrm{R}-3,125-130 \mathrm{~cm}$ ). Unit 211 extends from the top of the section of Hole 504B cored during Leg 140 (1621.8 mbsf) to $31 \mathrm{~cm}$ curated depth in Section 1 of Core 186 (1627.2 mbsf). As a short section of Hole 504B was drilled without coring, the total vertical thickness of the dike unit cannot be estimated, though the unit must have been greater than $5.4 \mathrm{~m}$ thick assuming that the recovered rocks are representative of the cored interval (10.2 m cored; $1.98 \mathrm{~m}$ recovered). Unit 227 extends from Section 140-504B-199R-1, $97 \mathrm{~cm}$ curated depth (1724.8 mbsf), through Core 140-504B-200R (1737.8 mbsf). Again, based on expanding the recovery to fit the cored interval (18.4 m cored; $5.7 \mathrm{~m}$ recovered), the unit is approximately $13.0 \mathrm{~m}$ thick. Adamson (1985), however, has noted that the typical dike contacts in Hole 504B are rotated by $30^{\circ}-40^{\circ}$ and dip from $50^{\circ}-60^{\circ}$. Any estimate of the width of a dike, therefore, must be corrected for this rotation. The few contacts recovered during Leg 140 were oriented similarly to those drilled earlier (Dick, Erzinger, Stokking, et al., 1992), and correcting the apparent thicknesses of Units 211 and 227 for an inferred dip of $55^{\circ}$ yields estimated dike thicknesses of 3.1 and $7.5 \mathrm{~m}$, respectively.

In contrast, approximately $50 \%$ of the dikes in the Leg 83 section, representing the upper $494 \mathrm{~m}$ of the dike section measured from the top of the transition zone, had widths of only 1-2 m, with the thickest dike only $7.5 \mathrm{~m}$ wide (Adamson, 1985). The Leg 140 dikes, then, reflect increasing average dike widths with depth. Units 211 and 227 , studied here, are situated approximately $1347 \mathrm{~m}$ and $1450 \mathrm{~m}$, respectively, below the top of the pillow lavas, and $781 \mathrm{~m}$ and $879 \mathrm{~m}$ below the top of the transition zone between sheeted dikes and pillow lavas. 


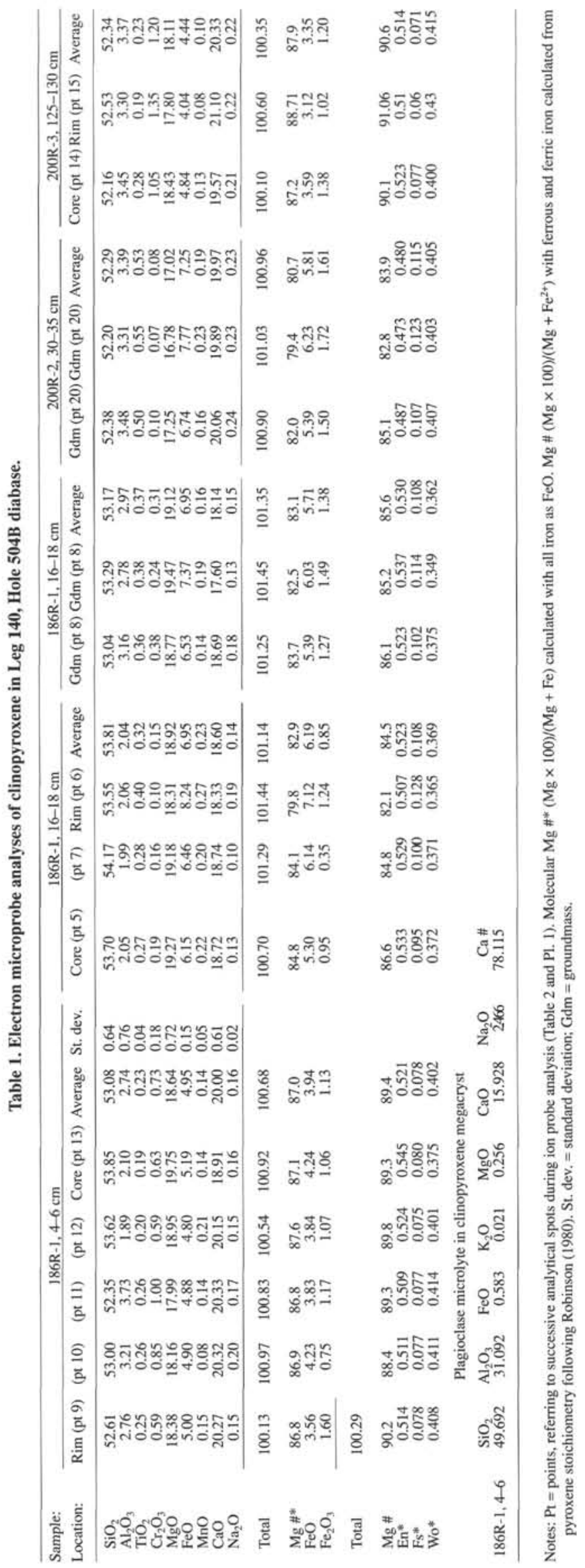

Geochemically, the Leg 140 dikes, including Units 211 and 227 , are identical to the pillow lavas and dikes higher in the section (Adamson, 1985) and can be classified as moderately evolved but unusually depleted normal mid-ocean-ridge basalt (N-type MORB) (Bryan et al., 1981). All lie within the composition range of the Group D basalts (Autio and Rhodes, 1983), which compose $98 \%$ of the dikes and lavas drilled down to $2000 \mathrm{~m}$ at Hole 504B. No geochemically enriched samples, similar to the rare enriched (E-type) and transitional (T-type) basalts higher in the hole (M, T, and E groups of Autio and Rhodes, 1983), were analyzed. The Group D basalts are atypical relative to normal MORB due to their exceptionally incompatibleelement-depleted and refractory compositions. Anomalously high bulk rock $\mathrm{Ca} / \mathrm{Na}$ ratios (5-8), are thought to be in equilibrium with plagioclase compositions up to $\mathrm{An}_{88}$, though they contain even more calcic plagioclase phenocrysts up to $\mathrm{An}_{90}$ (Autio and Rhodes, 1983; Kempton et al., 1985; Natland et al., 1983). Down to the bottom of the hole at $2000 \mathrm{mbsf}$ there is no systematic variation in primary igneous composition, although there are some noteworthy variations in elements sensitive to hydrothermal alteration (e.g., $\mathrm{K}, \mathrm{Zn}, \mathrm{Cu}, \mathrm{Sr}$; Dick, Erzinger, Stokking, et al., 1992). Moderately phyric units similar to 211 and 227 do show somewhat greater analytical scatter, and slightly high $\mathrm{Al}_{2} \mathrm{O}_{3}$, which can be attributed to the small sample size and variable phenocryst content as well as local plagioclase accumulation (Dick, Erzinger, Stokking, et al., 1992).

Units 211 and 227 have the same phenocryst assemblages, though the proportions differ. Unit 211 is classed as a moderately plagioclaseclinopyroxene-olivine, and Unit 227 as a plagioclase-olivineclinopyroxene phyric diabase (Dick, Erzinger, Stokking, et al., 1992). Similar moderately phyric basalts, varying largely in the relative proportions of the three phenocryst phases, constitute $70 \%$ of the Leg 140 section, and 26 of the 59 dikes described. Thus, moderately phyric diabase dikes are thicker on average than aphyric or slightly phyric varieties. Units 211 and 227 range from glomeroporphyritic to porphyritic, with a diabasic or doleritic groundmass consisting of plagioclase, augite, and oxides and sulfides. Olivine may have been present locally as a groundmass phase, but is now completely altered to talc, magnetite, sulfides, and clays. Plagioclase slightly exceeds augite in the groundmass.

\section{Crystal Clots and Phenocrysts}

Shown in Plate 1 are photomicrographs of the mineral clots, megacrysts, and phenocrysts analyzed for this paper, including three from Unit 211 (Pl. 1, Fig. 1a-c), and two from Unit 227 (Pl. 1, Fig. $2 \mathrm{a}-\mathrm{b})$. They are typical of the variety of textures and mineral assemblages exhibited by the various crystal clots described in the Initial Reports volume (Dick, Erzinger, Stokking, et al., 1992). Similar clots were also a notable feature of the diabase and pillow basalts drilled higher in Hole 504B (Kempton et al., 1985; Natland et al., 1983). These clots range from clinopyroxene and plagioclase megacrysts and xenocrysts, to clinopyroxene-plagioclase-olivine-spinel glomerocrysts and gabbroic xenoliths, with any combination of these phases occurring locally. Textural evidence is present for considerable resorption of clinopyroxene-bearing crystal clots and xenoliths of various compositions (Kempton et al., 1985; Dick, Erzinger, Stokking, et al., 1992; Natland et al., 1983). The detailed characteristics of the analyzed clinopyroxene crystals in each unit are described in the following sections.

\section{Unit 211}

A coarse, 2.5-cm, kelly green megacryst (Pl. 1, Fig. 1a, points 9-13; Tables 1 and 2) was analyzed in thin section (Sample 140504B-186R-1, 4-6 cm). In hand specimen, the pyroxene closely resembles the chromian diopside seen in mantle xenoliths. Its composition (Table 1), though fairly chromian $(0.6-1.0 \mathrm{wt} \%)$, is significantly more iron-rich $(\mathrm{Mg} /[\mathrm{Mg}+\mathrm{Fe}]=86.8-87.6)$ than diopside in 
Table 2. Ion microprobe analyses of Leg 140, Hole 504B diabase.

\begin{tabular}{|c|c|c|c|c|c|c|c|c|c|c|c|c|c|c|c|c|c|}
\hline Slide & Sample & $\mathrm{Pt}$ & Location & $\mathrm{La}$ & $\mathrm{Ce}$ & $\mathrm{Nd}$ & $\mathrm{Sm}$ & $\mathrm{Eu}$ & Dy & $\mathrm{Er}$ & $\mathrm{Yb}$ & $\mathrm{Ti}$ & V & $\mathrm{Cr}$ & $\mathrm{Sr}$ & $\mathrm{Y}$ & $\mathrm{Zr}$ \\
\hline 1 & $186 \mathrm{R}-1,4-6 \mathrm{~cm}$ & 9 & Rim & 0.047 & 0.249 & 0.676 & 0.538 & 0.164 & 1.245 & 0.774 & 0.713 & 1436 & 318 & 3599 & 3.2 & 8.7 & 3.9 \\
\hline 1 & $186 \mathrm{R}-1,4-6 \mathrm{~cm}$ & 10 & Inter. I & 0.033 & 0.329 & 0.861 & 0.582 & 0.289 & 1.328 & 0.826 & 0.869 & 1535 & 335 & 4887 & 3.4 & 9.7 & 5 \\
\hline I & $186 \mathrm{R}-1,4-6 \mathrm{~cm}$ & II & Inter. 2 & 0.058 & 0.340 & 0.872 & 0.751 & 0.271 & 1.740 & 1.016 & 1.074 & 1657 & 395 & 6295 & 3.2 & 10.4 & 5.6 \\
\hline 1 & $186 \mathrm{R}-1,4-6 \mathrm{~cm}$ & 12 & Inter. 3 & 0.052 & 0.377 & 0.867 & 0.522 & 0.176 & 1.085 & 0.695 & 0.606 & 1122 & 241 & 3379 & 2.9 & 6.5 & 3 \\
\hline 1 & $186 \mathrm{R}-1,4-6 \mathrm{~cm}$ & 13 & Core & 0.027 & 0.144 & 0.583 & 0.485 & 0.162 & 0.825 & 0.610 & 0.605 & 1096 & 249 & 3865 & 1.9 & 6 & 1.7 \\
\hline 4 & $186 \mathrm{R}-1,16-18 \mathrm{~cm}$ & 1 & Core & 0.031 & 0.225 & 0.650 & 0.508 & 0.245 & 1.433 & 0.847 & 0.962 & 1513 & 304 & 4264 & 3.3 & 9.1 & 4.9 \\
\hline 4 & $186 \mathrm{R}-1,16-18 \mathrm{~cm}$ & 2 & N Rim & 0.044 & 0.169 & 0.542 & 0.321 & 0.141 & 0.844 & 0.531 & 0.516 & 1131 & 237 & 3156 & 2.6 & 7.1 & 2.6 \\
\hline 4 & $186 \mathrm{R}-1,16-18 \mathrm{~cm}$ & 3 & Inter. & & 0.272 & 0.690 & 0.562 & 0.173 & 1.252 & 0.653 & 0.601 & 1621 & 339 & 5097 & 3.2 & 9.7 & 4.8 \\
\hline 4 & $186 \mathrm{R}-1,16-18 \mathrm{~cm}$ & 4 & S Rim & 0.081 & 0.317 & 0.609 & 0.535 & 0.135 & 0.700 & 0.434 & 0.523 & 1184 & 266 & 4050 & 3 & 6.7 & 2.8 \\
\hline 3 & $186 \mathrm{R}-1.16-18 \mathrm{~cm}$ & 5 & Core & 0.045 & 0.213 & 0.514 & 0.348 & 0.150 & 0.745 & 0.544 & 0.594 & 1327 & 273 & 1139 & 2.7 & 8.1 & 3.2 \\
\hline 3 & $186 \mathrm{R}-1,16-18 \mathrm{~cm}$ & 6 & $\operatorname{Rim}$ & 0.056 & 0.361 & 0.590 & 0.540 & 0.287 & 1.614 & 1.057 & 0.915 & 1956 & 373 & 377 & 3.6 & 13 & 4.3 \\
\hline 3 & $186 \mathrm{R}-1,16-18 \mathrm{~cm}$ & 7 & Inter. & 0.034 & 0.218 & 0.524 & 0.330 & 0.209 & 1.176 & 0.691 & 0.670 & 1404 & 297 & 933 & 2.6 & 9 & 2.9 \\
\hline 3 & $186 \mathrm{R}-1,16-18 \mathrm{~cm}$ & 8 & Gdm & 0.051 & 0.235 & 0.548 & 0.444 & 0.146 & 1.021 & 0.760 & 0.662 & 1197 & 235 & 1163 & 1.8 & 8 & 3 \\
\hline 7 & $200 \mathrm{R}-2,30-35 \mathrm{~cm}$ & 17 & Core & 0.095 & 0.400 & 0.757 & 0.394 & 0.215 & 1.225 & 0.717 & 0.598 & 1328 & 246 & 4757 & 4.1 & 6.3 & 3.3 \\
\hline 7 & $200 \mathrm{R}-2,30-35 \mathrm{~cm}$ & 18 & Rim & 0.093 & 0.588 & 0.768 & 0.450 & 0.226 & 1.193 & 0.755 & 0.662 & 1319 & 250 & 5656 & 4.3 & 7 & 3.5 \\
\hline 7 & $200 \mathrm{R}-2,30-35 \mathrm{~cm}$ & 19 & Corona & 0.115 & 0.463 & 0.718 & 0.616 & 0.287 & 1.556 & 0.930 & 0.936 & 3656 & 491 & 2394 & 7.4 & 16.4 & 23.4 \\
\hline 7 & $200 \mathrm{R}-2,30-35 \mathrm{~cm}$ & 20 & Gdm & 0.261 & 1.268 & 2.308 & 1.554 & 0.611 & 3.047 & 1.897 & 1.877 & 3354 & 480 & 438 & 5.2 & 22.4 & 13.9 \\
\hline 5 & $200 \mathrm{R}-3,125-130 \mathrm{~cm}$ & 14 & Core & 0.060 & 0.272 & 0.626 & 0.519 & 0.237 & 1.027 & 0.686 & 0.809 & 1377 & 299 & 5943 & 4 & 6.9 & 3.1 \\
\hline 5 & $200 \mathrm{R}-3,125-130 \mathrm{~cm}$ & 15 & Rim & 0.063 & 0.326 & 0.743 & 0.589 & 0.240 & 1.085 & 0.801 & 0.660 & 1557 & 297 & 8098 & 5.9 & 7.8 & 5.6 \\
\hline 5 & $200 \mathrm{R}-3,125-130 \mathrm{~cm}$ & 16 & Gdm & 0.119 & 0.797 & 1.787 & 0.990 & 0.434 & 2.408 & 1.460 & 1.550 & 4156 & 556 & 155 & 5.9 & 23.1 & 17.6 \\
\hline
\end{tabular}

Notes: $\mathrm{Pt}=$ points, referring to successive analytical spots during ion probe analysis. Inter. $=$ interior: $\mathrm{Gdm}=$ groundmass

abyssal peridotites $(\mathrm{Mg} \#=89.9-92.6$; Dick, 1989). Moreover, in thin section, the megacryst is anhedral, with an irregular margin, and encloses a mat of fine anhedral to euhedral plagioclase laths. This suggests that pyroxene and plagioclase nucleated contemporaneously, but with pyroxene apparently growing rapidly out from a single nucleus to enclose the more easily nucleated, and therefore abundant and smaller, plagioclase laths. In habit, the megacryst closely resembles a pyroxene oikocryst in a cumulate gabbro except for the fine grain size and lath-like morphology of the enclosed plagioclase, and the presence of strong irregular patchy sector zoning (Pl. 1, Fig. 1a). Analysis across the sector boundaries, as will be discussed below, shows discontinuous changes in major and trace element chemistry reflecting an origin related to crystal growth (Tables 1 and 2). These features preclude a mantle origin, suggesting instead rapid pyroxene crystal growth in an undercooled magma.

A coarse $8 \times 5 \mathrm{~mm}$ equant subhedral pyroxene $6 \mathrm{~cm}$ deeper in the core in a coarse, $1.7-\mathrm{cm}$ gabbroic clot was analyzed in thin section (Sample 140-504B-186R-1, 16-18 cm, thin section A, Pl. 1, Fig. 1b, points 5-7; Tables 1 and 2). The clot could be described as a gabbroic adcumulate with gabbroic hypidiomorphic inequigranular texture. Subophitic to subhedral coarse augite is intergrown with generally finer-grained stubby subhedral to equant anhedral plagioclase laths. Minor trapped intergranular mesostasis in the clot has diabasic texture. The pyroxene appears unzoned, as does the plagioclase. This clot may represent a "protogabbro" formed during the earliest stages of the formation of a crystal mush in the lower crust.

An additional pyroxene was analyzed in a second thin section of the same sample (thin section B, Pl. 1, Fig. 1c, points 1-4; Tables 1 and 2 ). It has a radically different morphology, consisting of a single, $12 \times 1.5 \mathrm{~mm}$, blade-like twinned crystal in a fine-grained diabasic groundmass. The pyroxene has numerous small devitrified glass inclusions and small stubby euhedral plagioclase laths. Though it is euhedral in form, there is a narrow selvage around the pyroxene where it is intergrown along a sutured contact with the adjacent groundmass plagioclase (Pl. 1, Fig. lb).

Each of the crystals analyzed from Unit 211 appears to have had a very different paragenesis. This is not an unusual situation for porphyritic MORBs, in which diverse crystal clots, xenocrysts, and phenocrysts have provided abundant evidence of magma-mixing and melt- rock interaction at depth (Dungan and Rhodes, 1978; Natland et al., 1983).

\section{Unit 227}

A small, $1 \times 1 \mathrm{~mm}$, subhedral equant augite (Pl. 1, Fig. 2a, points 17-19; Tables 1 and 2) was analyzed from thin section (Sample 140504B-200R-2, 30-35 cm). The crystal has irregular patchy sector zoning similar to that seen in the Unit 211 megacryst. This crystal has a 0.3 $\mathrm{mm}$ selvage or corona of intergranular augite intergrown with plagioclase microlites and laths that extend into the adjoining groundmass.

A large $10 \times 5 \mathrm{~mm}$ equant anhedral augite phenocryst was analyzed in thin section (Sample 140-504B-200R-3, 125-130 cm, Pl. 1, Fig, 2b, points 14-15; Tables 1 and 2). Although the crystal appears optically unzoned, microprobe analysis shows that the crystal is reversely zoned. It contains several subhedral stubby plagioclase laths, and has an irregular sutured margin where it is intergrown with plagioclase crystals extending from the adjoining diabase groundmass. Other plagioclase crystals in the groundmass are terminated against the side of the phenocryst.

The pyroxene crystals analyzed in Unit 227 are similar to the megacryst analyzed in Unit 211 in that they are intergrown with the groundmass plagioclase around their margins. The texture of Unit 227 also is seriate porphyritic, with a continuous gradation of phenocryst size down to that of the groundmass, rather than two separate size populations. This, we think, is evidence for nearly continuous crystallization beginning with onset of crystallization of the glomerocrysts and megacrysts and extending to shallow transport and dike emplacement.

\section{ANALYTICAL RESULTS}

\section{Major Elements}

Major element analyses of individual points on a representative suite of pyroxenes are given in Table 1 , and plotted in the pyroxene quadrilateral in Figure 1. Overall, there is considerable scatter, with compositions ranging from endiopside to augite. The pyroxene compositions from Units 211 and 227 (Cores 186R and 200R, respectively) overlap, although the groundmass pyroxenes from the two units differ substantially in wollastonite content, suggesting (in the absence of coexisting orthopyroxene) that the Unit 211 magma either was more calcic or crystallized at lower temperatures. The latter explanation may be consistent with the somewhat lower iron content 


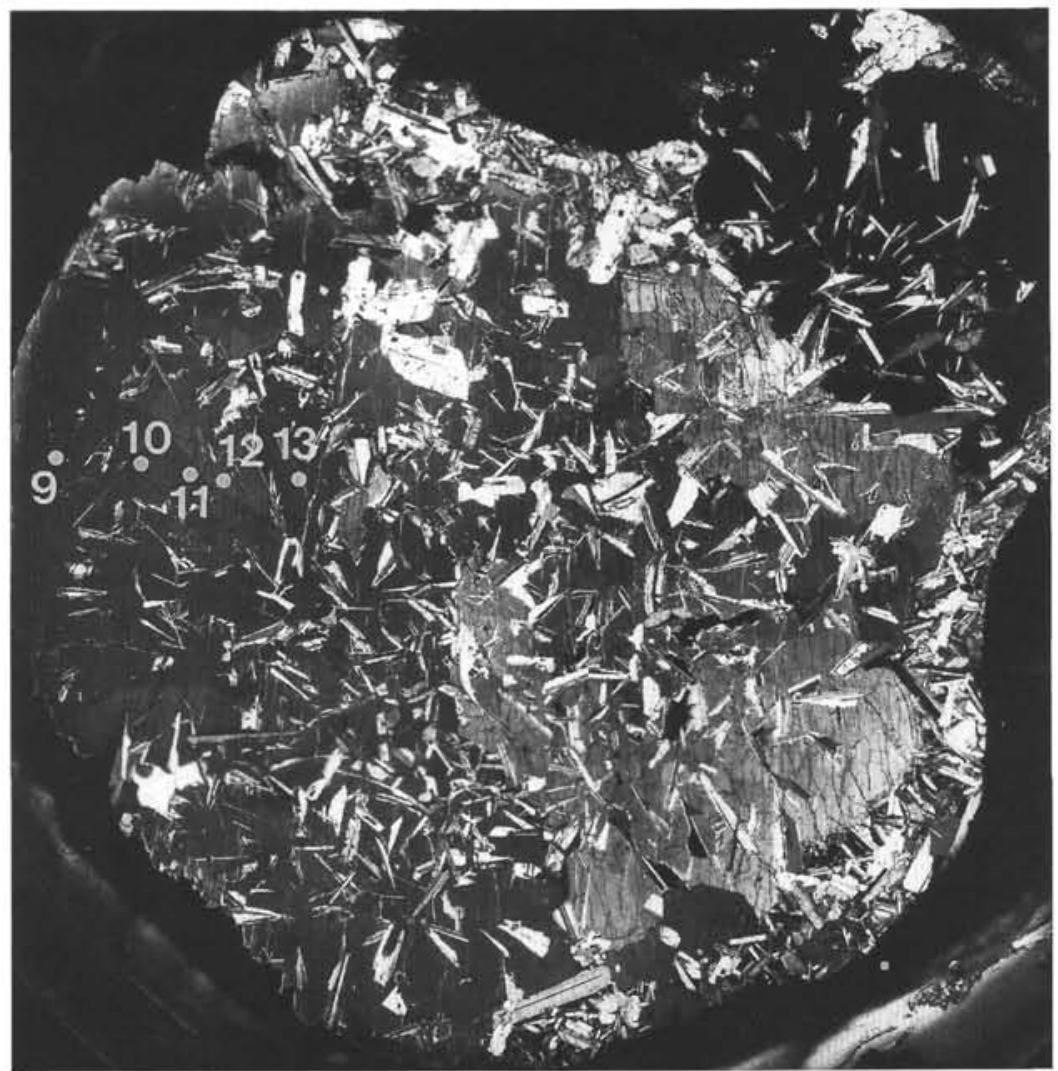

$1 \mathrm{a}$
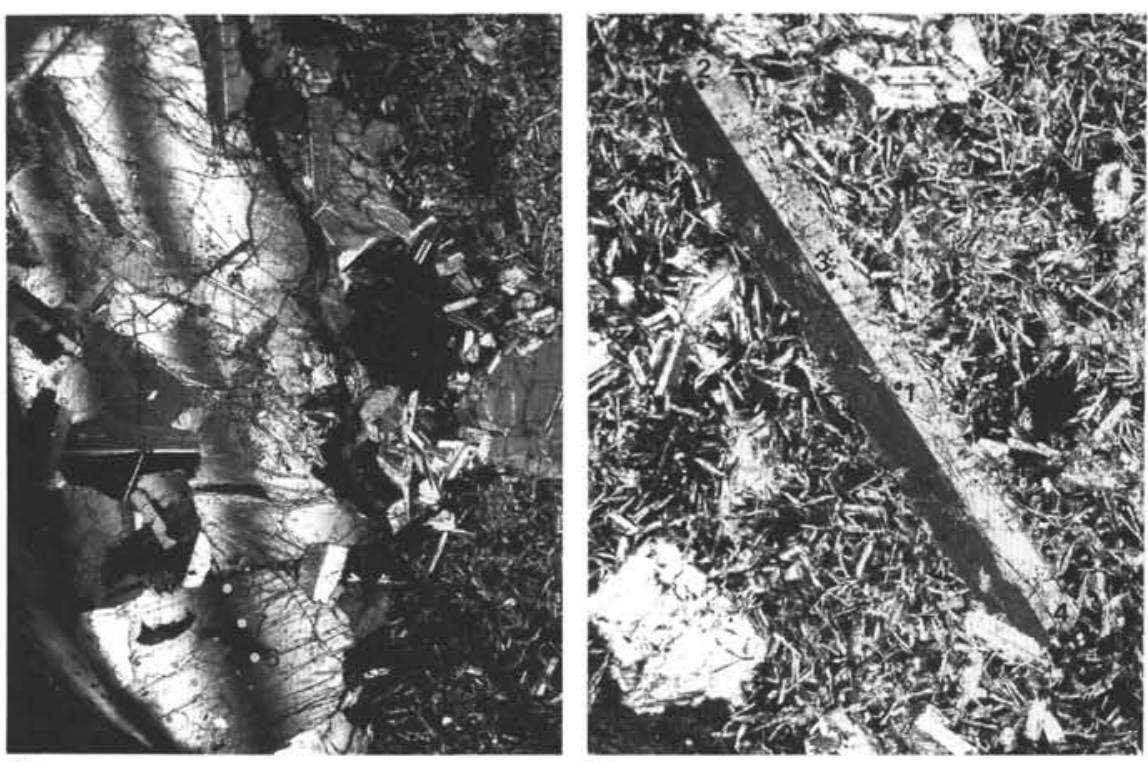

$1 \mathrm{~b}$

$1 \mathrm{c}$

Plate 1. 1. Unit 211 pyroxene-plagioclase-olivine porphyritic diabase dike megacrysts, phenocrysts, xenocrysts, and crystal clots (glomerocrysts) under cross-polarized light. Locations of analyses shown by white and black dots; major and trace element analyses are given in Tables 1 and 2 . 1a. 23-mm sector zoned chromian endiopside ( $\mathrm{Hd}<0.1,0.73 \mathrm{wt} \% \mathrm{Cr}_{2} \mathrm{O}_{3}$ ) megacryst enclosing a mat of feldspar microlites and microphenocrysts in thin section (Sample 140-504B-186R-1, 4-6 cm). 1b. Photomicrograph under cross-polarized light of $4.25 \times 5.25 \mathrm{~mm}$ subhedral augite phenocryst $\left(\mathrm{Hd}>0.1,0.15 \mathrm{wt} \% \mathrm{Cr}_{2} \mathrm{O}_{3}\right)$ in a pyroxene-plagioclase glomerocryst in Sample 140-504B-186R-1, 16-18 cm, thin section A. The glomerocryst contains a few small olivine pseudomorphs. 1c. $10.5 \times 1.2 \mathrm{~mm}$ twinned euhedral augite phenocryst with a mantle or corona of augite intergrown with plagioclase microlites from the groundmass. The pyroxene locally encloses small plagioclase microphenocrysts and is slightly zoned (Table 2). 2. Unit 227 moderately plagioclase-olivine-clinopyroxene phyric diabase glomerocryst and microphenocryst. 2a. 1.2-mm euhedral chromian endiopside or augite with a complex corona of intergrown augite and groundmass plagioclase microlites in Sample 140-504B-200R-2, 30-35 cm. 2b. $7 \times 4$ mm anhedral chromian endiopside $\left(\mathrm{Hd}<0.1,1.2 \mathrm{wt} \% \mathrm{Cr}_{2} \mathrm{O}_{3}\right.$ ) enclosing numerous small plagioclase microlites and stubby microphenocrysts in Sample 140-504B-200R-3, 125-130 cm. The endiopside is intergrown at rim with plagioclase microlites extending from the groundmass. 


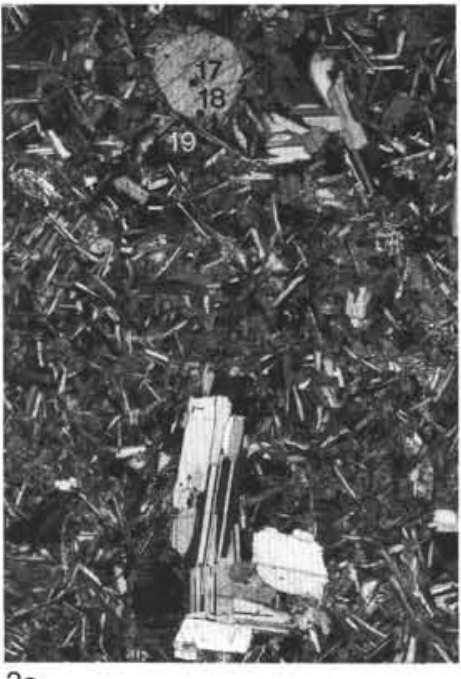

$2 a$

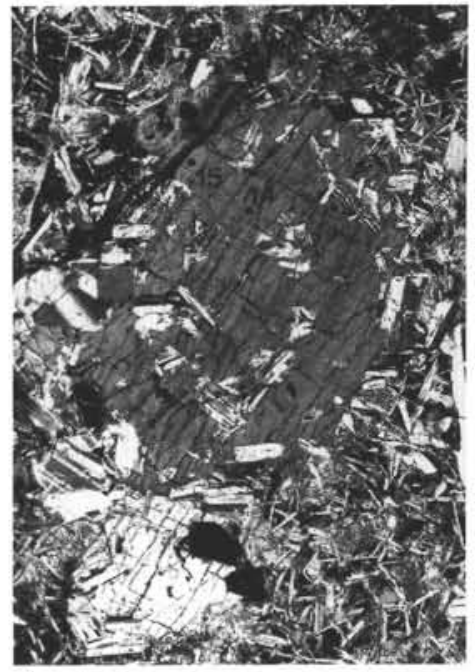

$2 \mathrm{~b}$

Plate 1 (continued).

of the Unit 211 groundmass pyroxene. The range in magnesium number ( $\mathrm{Mg}$ \#-all iron as $\mathrm{FeO}$ ) is large, with a good negative correlation of $\mathrm{Mg}$ \# to $\mathrm{TiO}_{2}$, and a somewhat poorer positive correlation with $\mathrm{Cr}_{2} \mathrm{O}_{3}$ (Fig. 2), consistent with pyroxene crystallization over a broad range of melt fractionation from the initial formation of phenocrysts to final crystallization of the groundmass pyroxene.

This simple pattern, however, becomes somewhat more complex when the $\mathrm{Cr}$-rich pyroxenes are examined. These include the coarse clinopyroxene megacryst in Unit 211 (points 9-13, Pl. 1, Fig. 1a) and the coarse anhedral equant phenocryst in Unit 227 (points 14 and 15, Pl. 1, Fig. 2b). In the latter crystal, where no sector zoning is evident, the crystal is reversely zoned, with $\mathrm{Cr}$-content and $\mathrm{Mg}$ \# increasing with decreasing $\mathrm{Ti}$ from core to rim. In the former crystal, however, the pattern is more complex. Although the total variation in $\mathrm{Mg} \#$ is small ( 86.8 to 87.6$), \mathrm{Cr}$ varies by nearly a factor of two, and $\mathrm{TiO}_{2}$ varies only from 0.19 to 0.26 . If anything, $\mathrm{TiO}_{2}$ increases with $\mathrm{Cr}$, while neither correlates with $\mathrm{Na}_{2} \mathrm{O}$. This pattern, as we will discuss below, may reflect crystallization kinetics. Notably, the largest jump in composition, between points 11 and 12 (Table 1), occurs across a sector zone boundary. This boundary was examined in more detail to determine its continuity, and to exclude the possibility that the two analytical points were fortuitously located on opposite sides of a chemical heterogeneity unrelated to the sector boundary. By rastering the electron beam over the boundary and producing a map of $\mathrm{Al}$ $\mathrm{K}$-alpha intensity, it was confirmed that the boundary was more than a simple optical discontinuity (such as a kink band) and corresponds to a discontinuous break in pyroxene composition. This compositional contrast appears to decrease and disappear along the boundary as the latter becomes optically invisible.

\section{Rare Earth Elements}

Rare earth and other trace element concentrations in the pyroxenes are given in Table 2; the concentrations of the rare earths normalized to chondrites are plotted in Figure 3. Values for Gd are interpolated from Dy and $\mathrm{Sm}$ for convenience in comparing these patterns to whole rock analyses from the literature.

As might be expected from the overwhelming preponderance of highly depleted N-type MORB in Hole 504B (98\% of the section), the clinopyroxenes have strongly depleted light rare earth element (LREE) concentrations. In several cases, however, the variation in the REE does not define a smooth curve, and liquids computed to be in equilibrium with pyroxenes are not depleted in LREE. As can be seen in Figure $3 \mathrm{~B},-\mathrm{D}$, and $-\mathrm{E}$, this produces rare earth patterns that cross the strongly depleted and very uniform patterns found in nearly all Hole 504B basalts. There are five likely explanations for this phenomenon: (1) analytical scatter during low level analysis of trace elements in pyroxene, (2) mixing of $\mathrm{N}$-and E-type MORB during crystal growth, (3) metasomatic alteration during upper greenschist facies metamorphism, (4) the distribution coefficients used are not correct for this case, and (5) local transient enrichment of the melt in LREE and rapid crystal growth as discussed in the "Trace Elements" section below. The first explanation is difficult to reconcile with the consistent patterns found in three different samples. Electronic noise in the detecting system during low-level analysis can give erroneous abundances at low levels for the LREE. The background levels during analysis, however, were uniformly low, which indicates that it is unlikely that significant electronic spiking occurred during counting. The second hypothesis is difficult to rule out entirely, but is not preferred, as it would seem a bit fortuitous that its effects are found in both Units 211 and 227, while E-type MORB composes only 2\% of the entire 504B section. In most cases only $\mathrm{La}$ and $\mathrm{Ce}$ are affected. We have found a similar increase (or kick) in the REE patterns of diopsides in some abyssal peridotites where hydrothermal amphibole is present. Pleochroic amphibole is present in the Leg 140 diabases, and hydrothermal amphibole is present in both Units 211 and 227 (Dick, Erzinger, Stokking, et al., 1992). Thus, this feature of the REE patterns might be attributed to hydrothermal alteration of the pyroxenes on further investigation. Finally, it is possible that the partition coefficients used here are inappropriate for the level of comparison we have made between the computed liquids and the observed whole rock analyses. At least some of the computed liquids, however, are identical to the patterns for the Hole 504B basalts. This is most notably the case for the cores of the Unit 211 (Core 186) pyroxenes.

Another notable feature of the REE patterns is the Eu anomalies seen in the Unit 211 endiopside megacryst and augite phenocryst and their calculated equilibrium liquids (Fig. 3A and 3B, respectively). Interestingly, both crystals have at least one point without an Eu 


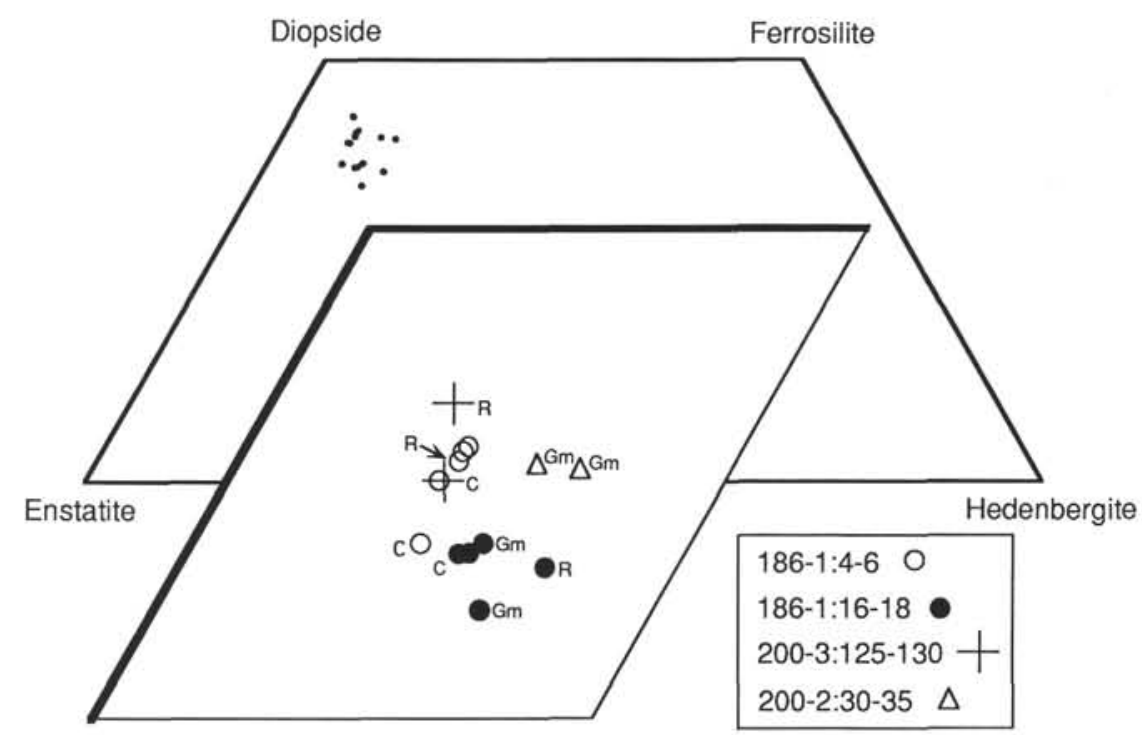

Figure 1. Electron microprobe analyses of clinopyroxene megacrysts, phenocrysts, and groundmass pyroxene in Unit 211 (140-504B-186R-1, 4-6 cm, and 16-18 $\mathrm{cm}$ ) and 227 diabases (140-504B-200R-2, 30-35 cm, and -200R-3, 125-130 cm).
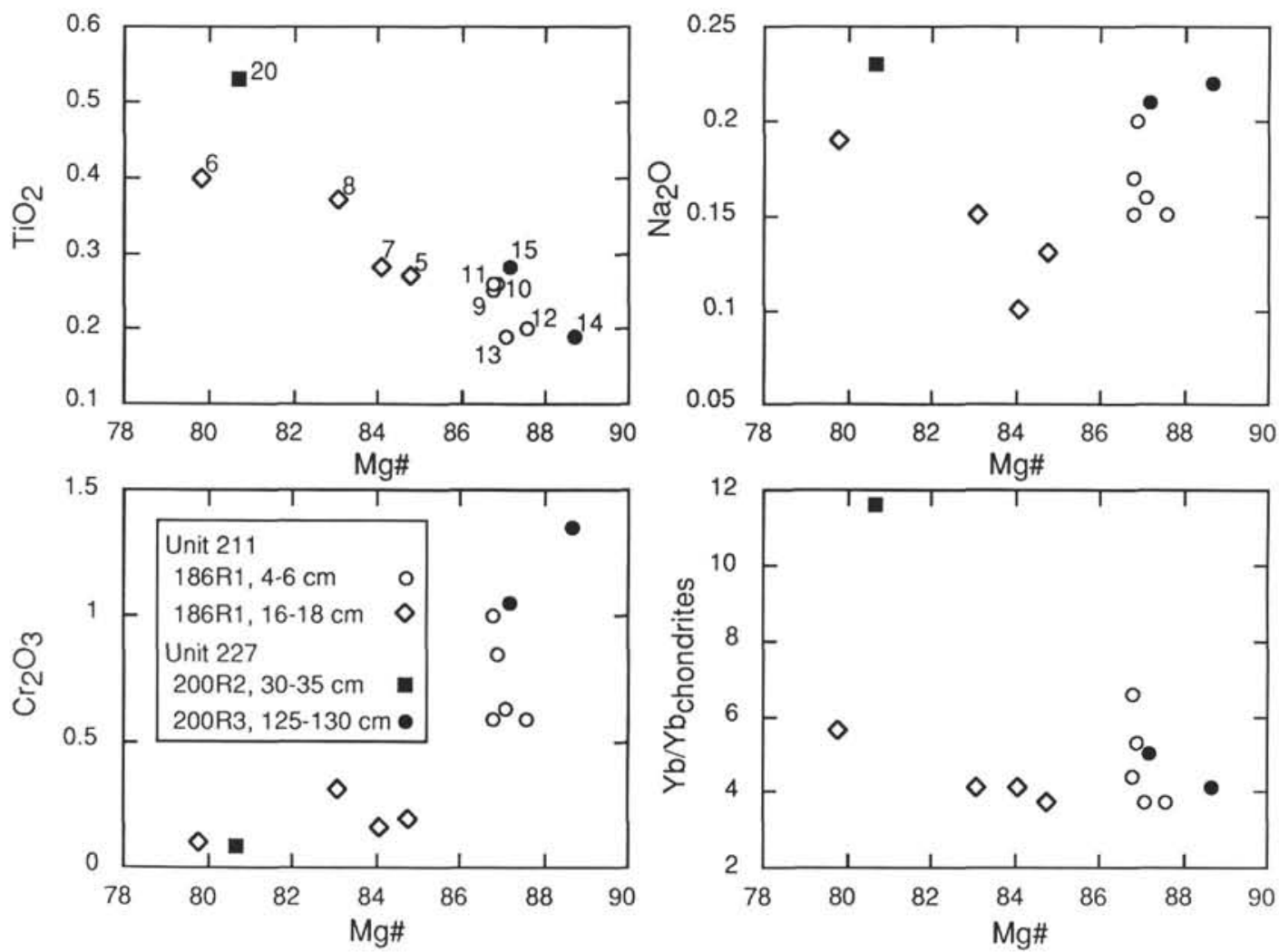

Figure 2. Plot of $\mathrm{Mg} \#([\mathrm{MgO} \times 100] /[\mathrm{MgO}+\mathrm{FeO} *])$ vs. weight percent $\mathrm{TiO}_{2}, \mathrm{Cr}_{2} \mathrm{O}_{3}, \mathrm{Na}_{2} \mathrm{O}$, and $\mathrm{Yb}$ normalized to chondrites for selected clinopyroxenes in Units 211 and 227 diabase dikes. Numbers in the upper left plot refer to the analytical points in Tables 1 and 2.

anomaly, most notably at both the core and rim of the phenocryst. We note also that the latter pyroxene is also reversely zoned, suggesting that it may have been incorporated into the melt during mixing of relatively primitive and evolved magmas at depth. The irregular appearance of the Eu anomaly, and its absence in the whole rock analyses taken from the literature for Hole 504B diabases and pillow basalts, suggest that the anomalies reflect local gradients in the melt produced locally due to heterogeneous nucleation and relatively rapid growth of pyroxene and plagioclase. Such a gradient would certainly be eliminated by magma mixing and flow of melt up a conduit during dike emplacement, explaining the absence of an Eu anomaly on the rim of the phenocryst. 

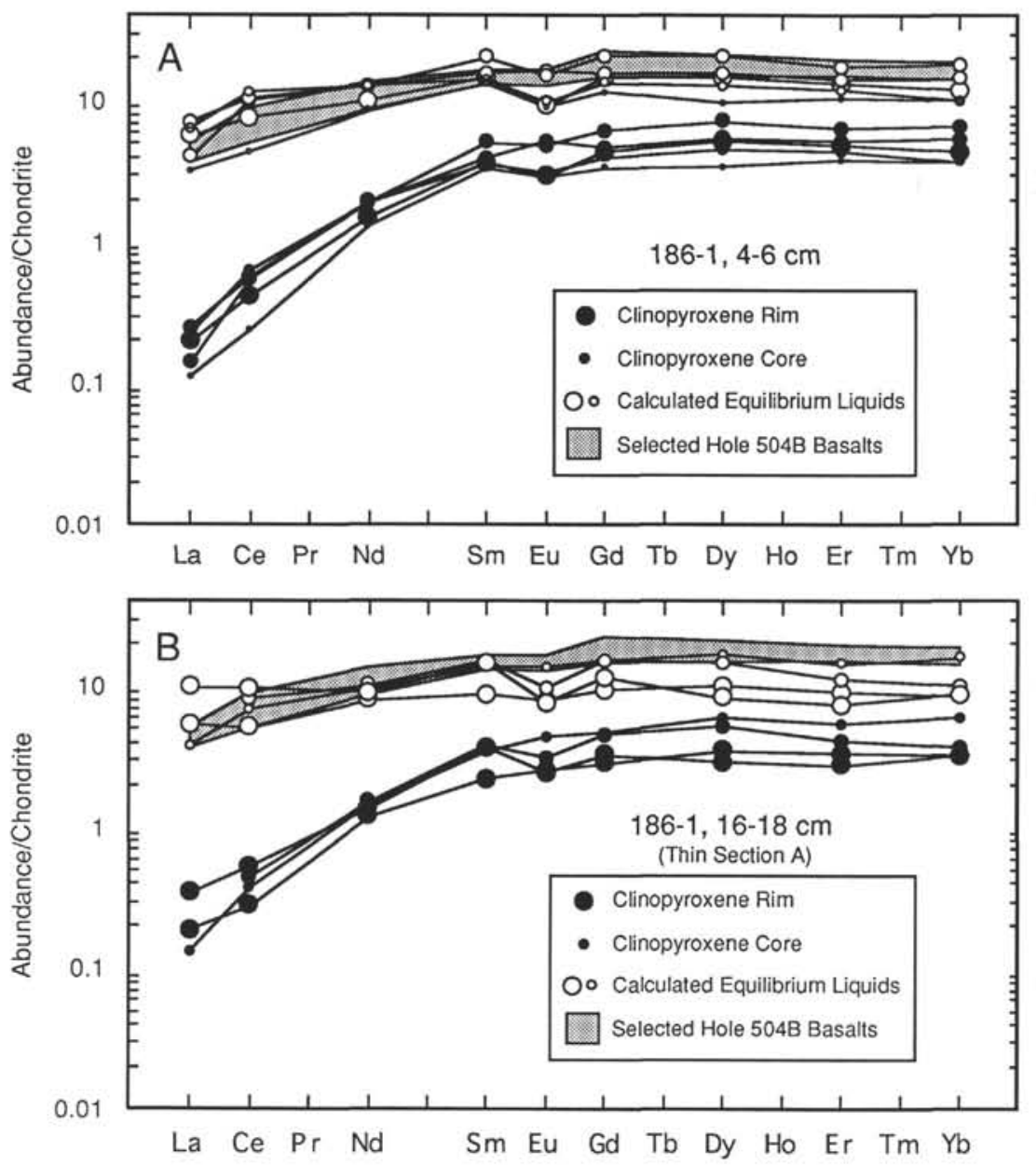

Figure 3. Rare earth element analyses normalized to chondrites using the values of Anders and Grevesse (1989) for Unit 211 and 227 diabase clinopyroxene megacrysts, phenocrysts, and groundmass. The compositions of representative Hole 504B basalts and diabases are shown for comparison. REE and trace element abundances in Hole 504B Leg 111 diabases from Shimizu et al. (1989). Ti, Zr, Y, Cr, Sr, and V from adjacent samples from Autio and Rhodes (1983). Rare earth and trace element abundances in Hole 504B Leg $69 / 70$ basalts from Hubberten et al. (1983). Vanadium values from Autio et al. (1989) are not from the same samples, but analyses closest to Hubberten's in core. The composition of the coexisting liquids is calculated using the partition coefficients provided by Sobolev and Shimizu (1993), with values for $\mathrm{Cr}$ and $\mathrm{V}$ from Hart and Dunn (1993). Gradation in dot size in the figure reflects progression from core (small dot) to rim (largest dot).

\section{Trace Elements}

In addition to the REE, we analyzed $\mathrm{Ti}, \mathrm{Cr}, \mathrm{Sr}, \mathrm{V}, \mathrm{Y}$, and $\mathrm{Zr}$ in the Unit 211 and 227 pyroxenes. For purposes of comparison and evaluation, we have plotted the compositions of liquids in equilibrium with these pyroxenes, normalized to chondrites, in Figure 4. Shown for comparison are patterns taken from the literature (Autio and Rhodes, 1983; Hubberten et al., 1983; Shimizu et al., 1989) for Leg 69/70 pillow basalts and Leg 111 diabase dikes.

As for Eu, many samples show strong negative $\mathrm{Sr}$ anomalies in the computed coexisting liquid compositions (Fig. 4). Sr is also strongly fractionated into plagioclase. No basalts or diabases in Hole 504B have negative $\mathrm{Sr}$ and Eu anomalies. Therefore, their presence in the clinopyroxenes is best explained as a result of heterogeneous nucleation of plagioclase and pyroxene in the cooling magma, and local $\mathrm{Sr}$ and Eu melt-depletion by plagioclase crystallization.

The second feature of interest is the strong enrichment of $\mathrm{Cr}$ in many computed liquids relative to the whole-rock compositions (Fig. 4). This could reflect local enrichment of pyroxene in $\mathrm{Cr}$ due to interface kinetics during crystallization at high growth rates rather than high concentration in the liquid (Shimizu, 1983). This might explain the very large variations in $\mathrm{Cr}$ in the Unit 211 megacryst without accompanying changes in Ti. Alternatively, different rates of crystal growth at different crystal faces may produce very different local compositional gradients in the liquid, and compositional sector zoning in the pyroxene. A rapidly growing crystal face might cause the melt to become locally depleted in $\mathrm{Cr}$ relative to $\mathrm{Ti}$ compared to melt adjacent to a slowly growing face. The megacryst, however, is an equant crystal, not the bladed variety, and it appears that the growth rates of different crystal faces in the thin section were similar. More- over, this begs the question of the absence of rocks in Hole 504B suitably enriched in $\mathrm{Cr}$ to be in equilibrium with the $\mathrm{Cr}$-rich portions of the megacrysts. Thus, we prefer the explanation that the effective $K_{D}$ for $\mathrm{Cr}$ is strongly affected by interface kinetics during rapid crystal growth (Shimizu, 1983) for both the presence of the sector zoning and the remarkable local enrichment of $\mathrm{Cr}$ in some of the pyroxenes.

\section{CONCLUSIONS}

The clinopyroxene megacrysts and clots found in the Leg 140 Hole 504B diabases reflect a complex history of crystal growth. In some cases, chemical evidence supports the concept that some are exotic crystals reflecting early stages of melt crystallization at depth. Large compositional variations are also found, which appear to be due to crystal growth phenomena and heterogeneous nucleation in the early stages of melt crystallization prior to intrusion of the dikes. The strong $\mathrm{Sr}$ and $\mathrm{Eu}$ anomalies found in the trace element patterns are curious and are explained here as the result of heterogeneous nucleation and growth of plagioclase and pyroxene in the magma, producing strong local concentration gradients near the crystal clots. The absence of these anomalies in some of the cores and rims of the grains, and in some groundmass pyroxene, argues that these gradients may be transient. The large compositional contrasts across sector zone boundaries in equant crystals may be due to variations in the effective partition coefficient due to interface kinetics as suggested by Shimizu (1983). This study is exploratory in nature, and more definitive interpretation than provided below awaits a more complete investigation.

A number of different scenarios might explain the observations made here. Both aphyric and phyric lavas occur in the pillow basalt and dike sections, which suggest that the heterogeneous phenocryst 

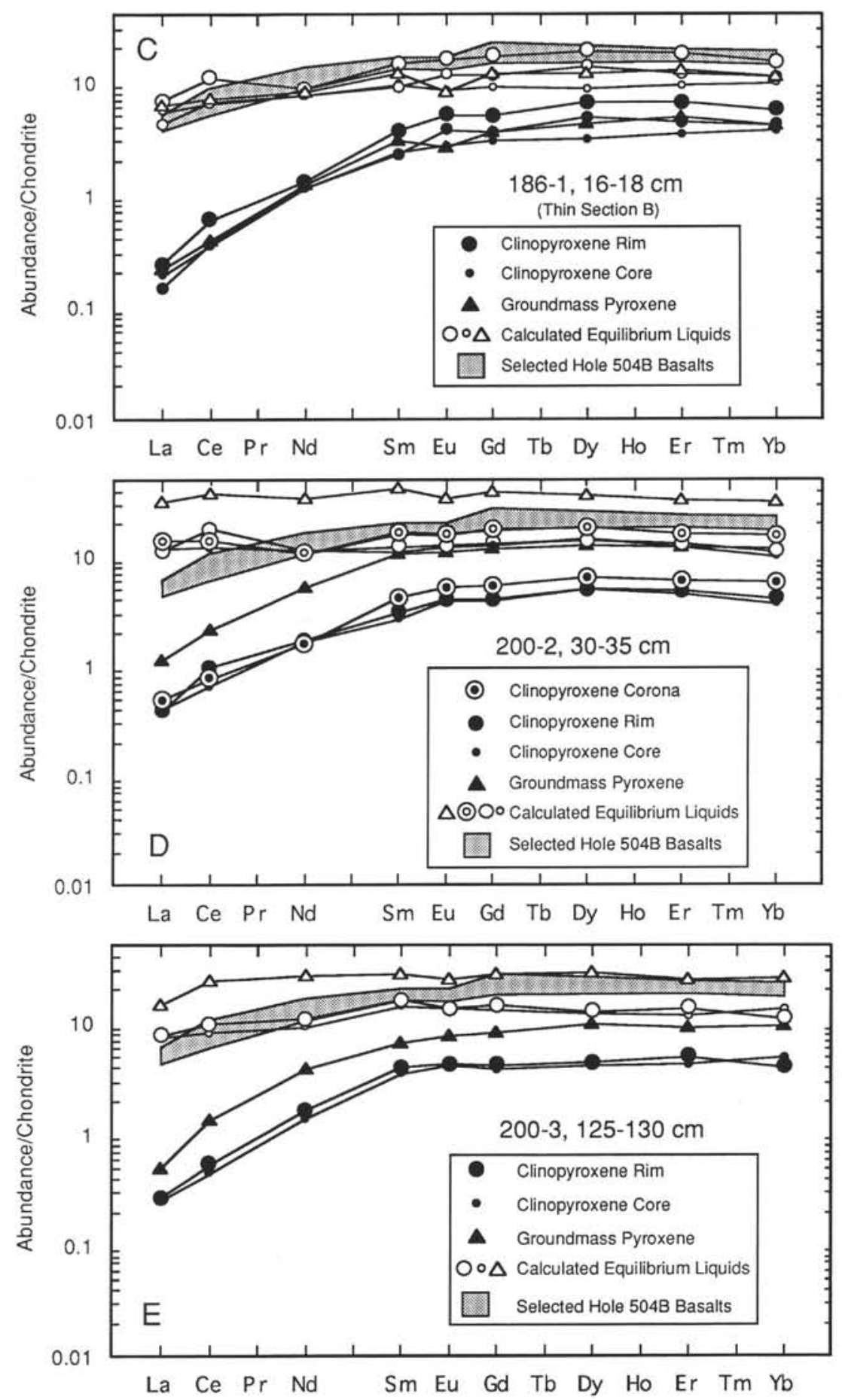

Figure 3 (continued).

assemblages in the dikes we studied are not directly related to shallow melt transport, but reflect deeper phenomena. The phenocrysts are also quite magnesian, and would be in equilibrium with fairly primitive melts, eliminating the hypothesis that they represent eruption of a crystal-rich stagnant melt from a fractionated crystal mush in the lower crust. The crystal clots, studied here, also reflect heterogeneous coarse crystal growth and local transient trace element disequilibrium, consistent with a period of rapid crystal growth and undercool- ing of the melt-not a period of slow crystal growth in a stagnating magma. Phyric dikes are also, on average, thicker than aphyric dikes, suggesting that the phenomena causing crystallization of the phenocrysts occurred at a time when the melt-storage system in the lower crust was inflated.

The scenario we think best fits the observations would be the input of fresh hot melt into the lower crust from the mantle at the end of a relatively amagmatic cycle. This would inflate the melt storage sys- 


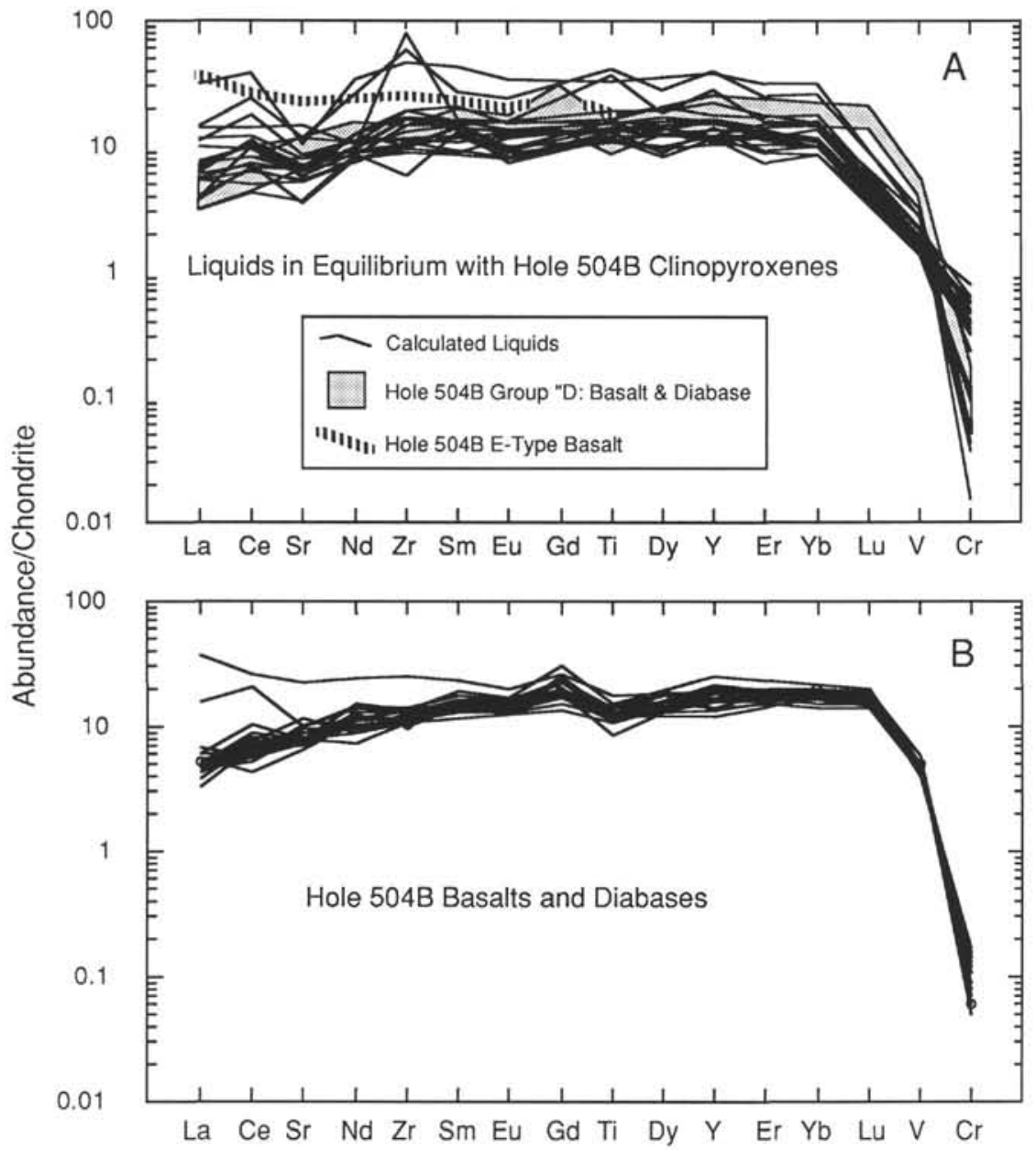

Figure 4. A. Trace element compositions of Unit 211 and 227 diabase clinopyroxene phenocrysts and groundmass normalized to chondrites using the values of Anders and Grevesse (1989). Field of Group D (Autio and Rhodes, 1983) Hole 504B MORB is shown for comparison. B. Hole 504B Leg 69 pillow basalts and Leg 111 diabases are shown for comparison (data sources given in caption for Fig. 3). tem and produce a brief period of melt-undercooling as the fresh magma came into equilibrium with the cooler rock and pre-existing stagnated melt. This also can explain the presence of reverse zoning in one of the pyroxenes analyzed. Subsequently, many of the crystals that formed during this phase, having a heterogeneous composition, would likely be replaced by an equilibrium assemblage.

This scenario explains the lack of $\mathrm{Eu}$ and $\mathrm{Sr}$ anomalies in pillow basalts and whole rock analyses of the dikes from Hole 504B, the initial lack of these anomalies at the cores of the clinopyroxene phenocrysts, and their absence locally on the rims of the crystals. There would be no Eu and $\mathrm{Sr}$ anomalies present in the melt at the onset of undercooling and the initial nucleation of the pyroxenes. It is, however, a common observation in abyssal basalts that different phases tend to nucleate together and are often found adhering to one another, as is the case in the diabases studied here. Early pyroxenes, then, are likely to grow adjacent to other crystals. Thus, development of local $\mathrm{Sr}$ and Eu anomalies in the melt in areas of rapid plagioclase nucleation and growth are likely to occur near pyroxenes, which in turn incorporate them into their trace element signature as they grow. As the rate of growth of both plagioclase and pyroxene slowed, however, convection and diffusive exchange within the melt would eliminate these local chemical heterogeneities in the melt, and the Eu and $\mathrm{Sr}$ anomalies would disappear.

Because the undercooling cycle occurs during input of fresh melt and, consequently, inflation of the conduit and melt storage system in the lower crust, dikes intruded during this phase would likely be larger than those intruded at other stages. The chemically heterogeneous assemblage of crystal clots, however, which we think characteristic of such magmas, is unlikely to be widely preserved in the lower crust. This would be due to reequilibration in the melt between inflation phases, and grain-boundary-migration and recrystallization in a compacting crystal mush, as gabbros solidify within the conduit system: consistent with the absence of such heterogeneous crystals in many MORBS and dredged gabbros.

\section{ACKNOWLEDGMENTS}

We would like to thank Dr. Nobu Shimizu for his assistance in ion microprobe analysis and for the many illuminating discussions that occurred as the results issued forth, on which the interpretations presented in this paper are greatly dependent. Dr. Tim Grove of the Massachusetts Institute of Technology provided access to the electron microprobe and presented additional helpful insights into the crystallization of zoned phenocrysts as well as a review of the final manuscript. We would also like to thank S.A. Morse and P.B. Kelemen for their helpful reviews. Dr. Michael Jercinovic provided assistance and entertainment during electron microprobe analysis, and we are grateful for his staying late to help us. Linda Angeloni prepared the polished thin sections for analysis. The Ocean Drilling Program at Texas A\&M University made the whole thing possible, particularly the Operations Superintendent Gene Pollard, who is either very lucky or very skilled-probably both. Without Captain Tom Ribbens and Drilling Superintendent Jack Tarbutton and their diligent crews it would have been hard to have gotten there, and even harder to have drilled. The food was quite good, even if we never did find the bar. This work was supported by a grant from the USSP(P.O. \# 20647), and this is Woods Hole Oceanographic Institution contribution \# 8678. 


\section{REFERENCES}

Adamson, A.C., 1985. Basement lithostratigraphy, Deep Sea Drilling Project Hole 504B. In Anderson, R.N., Honnorez, J., Becker, K., et al., Init. Repts. DSDP, 83: Washington (U.S. Govt. Printing Office), 121-127.

Anders, E., and Grevesse, N., 1989. Abundances of the elements: meteoritic and solar. Geochim. Cosmochim. Acta, 53:197-214.

Autio, L.K., and Rhodes, J.M., 1983. Costa Rica Rift Zone basalts: geochemical and experimental data from a possible example of multistage melting. In Cann, J.R., Langseth, M.G., Honnorez, J., Von Herzen, R.P., White, S.M., et al., Init. Repts. DSDP, 69: Washington (U.S. Govt. Printing Office), 729-745.

Autio, L.K., Sparks, J.W., and Rhodes, J.M., 1989. Geochemistry of Leg 111 basalts: intrusive feeders for highly depleted pillows and flows. In Becker, K., Sakai, H., et al., Proc. ODP, Sci. Results, 111: College Station, TX (Ocean Drilling Program), 3-16.

Bryan, W.B., Thompson, G., and Ludden, J.N., 1981. Compositional variation in normal MORB from $22^{\circ}-25^{\circ} \mathrm{N}$ : Mid-Atlantic Ridge and Kane Fracture Zone. J. Geophys. Res., 86:11815-11836.

Dick, H.J.B., 1989. Abyssal peridotites, very slow spreading ridges and ocean ridge magmatism. In Saunders, A.D., and Norry, M.J. (Eds.), Magmatism in the Ocean Basins. Geol. Soc. Spec. Publ. London, 42:71-105.

Dick, H.J.B., Erzinger, J., Stokking, L.B., et al., 1992. Proc. ODP, Init. Repts., 140: College Station, TX (Ocean Drilling Program).

Dungan, M.A., and Rhodes, J.M., 1978. Residual glasses and melt inclusions in basalts from DSDP Legs 45 and 46: evidence for magma mixing. Contrib. Mineral. Petrol., 67:417-431.

Hart, S.R., and Dunn, T., 1993. Experimental CPX/melt partitioning of 24 trace elements. Contrib. Mineral. Petrol., 113:1-8.

Hubberten, H.-W., Emmermann, R., and Puchelt, H., 1983. Geochemistry of basalts from Costa Rica Rift Sites 504 and 505 (Deep Sea Drilling Project Legs 69 and 70). In Cann, J.R., Langseth, M.G., Honnorez, J., Von Herzen, R.P., White, S.M., et al., Init. Repts. DSDP, 69: Washington (U.S. Govt. Printing Office), 791-803.

Johnson, K.T.M., Dick, H.J.B., and Shimizu, N., 1990. Melting in the oceanic upper mantle: an ion microprobe study of diopsides in abyssal peridotites. J. Geophys. Res., 95:2661-2678.
Kempton, P.D., Autio, L.K., Rhodes, J.M., Holdaway, M.J., Dungan, M.A., and Johnson, P., 1985. Petrology of basalts from Hole 504B, Deep Sea Drilling Project, Leg 83. In Anderson, R.N., Honnorez, J., Becker, K., et al., Init. Repts. DSDP, 83: Washington (U.S. Govt. Printing Office), 129-164.

Natland, J.H., Adamson, A.C., Laverne, C., Melson, W.G., and O'Hearn, T., 1983. A compositionally nearly steady-state magma chamber at the Costa Rica Rift: evidence from basalt glass and mineral data, Deep Sea Drilling Project Sites 501, 504, and 505. In Cann, J.R., Langseth, M.G., Honnorez, J., Von Herzen, R.P., White, S.M., et al., Init. Repts. DSDP, 69: Washington (U.S. Govt. Printing Office), 811-858.

Robinson, P., 1980. The composition space of terrestrial pyroxenes: internal and external limits. In Prewitt, C.T. (Ed.), Pyroxenes. Rev. Mineral., 7:419-494.

Shimizu, H., Mori, K., and Masuda, A., 1989. REE, Ba, and Sr abundances and $\mathrm{Sr}, \mathrm{Nd}$, and $\mathrm{Ce}$ isotopic ratios in Hole 504B basalts, ODP Leg 111, Costa Rica Rift. In Becker, K., Sakai, H., et al., Proc. ODP, Sci. Results, 111: College Station, TX (Ocean Drilling Program), 77-83.

Shimizu, N., 1983. Interface kinetics and trace element distribution between phenocrysts and magma, In Augustithis, S.S. (Ed.), The Significance of Trace Elements in Solving Petrogenetic Problems and Controversies: Athens (Theophrastus Publ.), 175-195.

Sobolev, A.V., and Shimizu, N., 1993. Ultra-depleted primary melt included in an olivine from the Mid-Atlantic Ridge. Nature, 363:151-154.

Abbreviations for names of organizations and publications in ODP reference lists follow
the style given in Chemical Abstracts Service Source Index (published by American
Chemical Society).

Date of initial receipt: 15 July 1993

Date of acceptance: 14 April 1994

Ms 137/140SR-003 